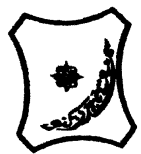

Bayero Journal of Pure and Applied Sciences, 10(2): 283 - 291

Received: November, 2017

Accepted: December, 2017

ISSN $2006-6996$

\title{
THE INFLUENCE OF PHYSICOCHEMICAL CHARACTERISTICS OF A NON-EDIBLE OIL OF YELLOW OLEANDER SEED ON ITS FUEL PROPERTIES
}

*Dallatu, Y.A., Agbaji, E. B. and Ajibola, V.o.

Department of Chemistry, Ahmadu Bello University, Zaria, Nigeria.

*Corresponding Author: yakubudallatu@yahoo.com ; 08068087732

\begin{abstract}
In this study, oil was extracted from yellow oleander (YO) seed and the yield was found to be $64.7 \%$. The physico-chemical parameters of the yellow oleander seed oil (YO) were assessed following the ASTM standard methods, and found to have iodine value of 75.82 and calorific value of $13.79 \mathrm{MJ} / \mathrm{Kg}$. Other physicochemical parameters determined were acid value (1.26), peroxide value (3.0 meq/ $\mathrm{kg})$ and specific gravity $\left(0.88406 \mathrm{~g} / \mathrm{cm}^{3}\right)$. Some Fuel properties of the oil include high flash points $\left(192^{\circ} \mathrm{C}\right)$, kinematic viscosity $\left(23.23 \mathrm{~mm}^{2} / \mathrm{s}\right)$ and cloud point of $14{ }^{\circ} \mathrm{C}$. The FTIR analyses of the YO showed the carbonyl functional group of the triglycerides at $1739 \mathrm{~cm}^{-1}$ to $1745 \mathrm{~cm}^{-1}$ as the most intense and prominent bands. The fatty acid composition of the oil was determined using the Gas chromatography - mass spectrometry (GC-MS) and the saturated fatty acid of yellow oleander seed oil was found to be $38.11 \%$ with palmitic acid (23.61\%) and stearic acid (10.78\%). The GC-MS result showed about $80 \%$ saturated/ monounsaturated fatty acids in the YO, signifying high potential for biodiesel production.
\end{abstract}

KEY WORDS: yellow oleander seed oil, biodiesel, fuel, triglyceride, saturated fatty acid

\section{INTRODUCTION}

Fats and oils are usually triglycerides, generally with a number of branched chains of different lengths and different degrees of saturation. However, their physico-chemical characteristics influence the quality of their fuel properties and may affect the stability and other properties of the oil. The idea to use vegetable oils as fuels is more than a hundred years old. Rudolf Diesel conducted an engine tests on plant oils at the World's Exhibition in Paris in 1900 (Shay, 1993). The idea for this test had apparently stemmed from the French government, who was searching for a means of domestic fuel production in their African colonies. Several other European countries took interest in the idea after the Exhibition. However, Petroleum-based fuels soon became available in large quantities at comparatively low cost and interest in plant oils diminished. In the early 1970s, however, world-wide oil crises and growing ecological awareness led to the rediscovery of plant oils as possible alternatives to hydrocarbon-based fuels but with some challenges.

The price of feedstock (vegetable oil) is one of the most significant factors, which constitute approximately $75-88 \%$ of the total biodiesel production cost (Ahmad et al., 2011). Another major limiting factor of biodiesel is the inverse relationship between its oxidation stability and its cold flow properties which depend on the physico-chemical characteristics of the oil.

The type of feedstock in biodiesel production is one important parameter that needs great attention (Jahirul et al., 2013). Different nations are looking into different vegetable oils as potential diesel fuel replacement. The traditional raw materials used for biodiesel production are mostly the conventional edible oils. They include rapeseed oil, sunflower seed oil, soybean oil, palm oil, linseed oil; beef tallow and recycled frying oil among others (Aransiola et al., 2012; Izah and Ohimain 2013), which are highly competitive for food and have placed strain on food production, price and availability. High cost of edible vegetable oils is a major challenge for economic viability of biodiesel industries and can hardly be afforded by poor and underdeveloped countries. It is therefore inevitable to look for non-edible but economically viable feed stocks as an alternative to edible vegetable oils (Khandelwal and Chauhan, 2012).

A number of plant oils contain substances which make them unsuitable for consumption. Among non-edible oils already used for biodiesel production, castor oil, physic nut oil, jatrophas curcas oil, and various oils deserve special attention. Castor (Ricinus communis) seed contains ricin, a highly toxic lectin is not fit for nutritional purposes due to its laxative effect (Tunaru et $a /, 2012$ ). This property is ascribed to the fact that castor oil contains up to $90 \%$ of linoleic acid. Several feedstocks such as karanja (Pongamia glabra) (Patel et al, 2013), field pennycress (Thlaspi arvense L.) ( Moser et al., 2009), rubber (Hevea brasiliensis) (Hassan et al., 2014; Abdulkadir et al., 2014), Jatropha curcas (Peng and Zhou, 2014; WU et al., 2010), terminalia (Terminalia belerica Robx.) (Atabani et al., 2015), mahua (Madhuca indica) (Padhi and Singh, 2010 and Raheman and Ghadge, 2007), etc. are already under consideration by the world community.

In Nigeria, the use of biodiesel as an alternative source of energy is being considered but the type of feedstock and the effect of the physico-chemical characteristics of the oils on the quality of the biodiesel are yet to be fully investigated hence the need for this research. 
Some recent studies in Nigeria, show the utilization of non-edible oils for biodiesel production from Jatropha curcas L. (Raufu et al., 2014; Mohammed et al., 2014) and Neem seed oils (Aransiola et al.,2012; Zaku et al., 2012). Oluwaniyi and Ibiyemi (2007), have reported on the high oil yield of Thevetia peruviana seed. In this context, Thevetia peruviana) seed oil could be an excellent feedstock for biodiesel industries and deserves attention (Yarkasuwa et al., 2013). The choice of the non-edible plant seed of yellow oleander will not affect food security is an attempt to find a suitable renewable raw material for biodiesel production in Nigeria.

\section{MATERIALS AND METHODS}

In this work, we are reporting on the extractability and yield of yellow oleander seed oil. The following physico-chemical characteristics of the oil were determined: saponification value, acid value, iodine value, peroxide value, specific gravity, free fatty acid and refractive index. The Gas chromatography Mass spectroscopy (GC-MS) of Agilent 7890A series chromatograph equipped with a Mass Spectometer Detector (Make No. 5975) was employed for the analysis of the fatty acid profile. The FTIR of Yellow oleander seed oil was analysed for the functional groups that qualifies it as triglycerides. The following fuel properties were determined: ASTM colour, kinematic viscosity, flash point, pour point, cloud point, cetane number, sulphur content and calorific value. The fuel properties of the oil were compared with the latest American Standard for Testing Material (ASTM D 6751) and European standard for biodiesel.

\section{Material Collection and Lipid Extraction}

Yellow oleander seed oil: The non-edible Yellow oleander seeds were collected from the residential area of the Ahmadu Bello University main campus Zaria in the month of November and December and dried in the sunlight for a week. The seeds were cleaned, de-shelled and dried at high temperature of $100-105^{\circ} \mathrm{C}$ for 35 mins and decorticated manually to obtain the kernel. The kernels were removed from the shell and crushed to produce fine seed flour from which the oil was extracted using an oil press machine. The expelled oil was pressed in a filter cloth to hold back the extraneous materials, the oil separates out into a container leaving behind the "oil cake" according to methods of AOAC (1984). The yield of the oil was then calculated thus:-

$$
\% \text { oil yield }=\frac{\text { weight of oil expelled in g } \times 100}{\text { Weight of seed flour used }}
$$

The oil was stored at $4{ }^{\circ} \mathrm{C}$ to avoid rancidity.

\section{GC-MS Analyses for the Fatty Acids Profile of the Oil \\ The oil was methylated using potassium} hydroxide/methanol and the methyl esters extracted were dissolved in hexane. The Gas Chromatograph was equipped with a capillary column $30 \mathrm{~m}$ x $250 \mu \mathrm{m} \times$ $0.25 \mu \mathrm{m}$ dimension packed with non-polar HP-5. The column temperature was programmed initially at $100^{\circ} \mathrm{C}$ (held for 20 minutes), and then increased to $180{ }^{\circ} \mathrm{C}$ at the rate of $10{ }^{\circ} \mathrm{C} / \mathrm{min}$, held for 10 minutes and then increased to $290{ }^{\circ} \mathrm{C}$. The inlet temperature was set at $300^{\circ} \mathrm{C}$. The samples were first methylated to the more volatile methyl esters by dissolving $0.125 \mathrm{gm}$ of the oil in $5.0 \mathrm{~cm}^{3}$ of $\mathrm{n}$-hexane. This was then followed by the addition of $0.5 \mathrm{ml}$ of $5 \mathrm{M}$ sodium methoxide and vigorously shaken. The methylated sample was diluted in hexane and $1 \mu$ of this solution was injected into the column at a temperature of $230^{\circ} \mathrm{C}$, and a detector temperature of $240{ }^{\circ} \mathrm{C}$, while the nitrogen gas was maintained at 5.5Psi. The injection was performed in split mode with a split ratio of $50: 1$. Helium was used as the carrier gas at a flow rate of $0.8 \mathrm{~cm}^{3} / \mathrm{m}$. The fatty acids were eluted as peaks. The identification of peaks was done by comparison of their retention time and mass spectra with Mass Spectral Library (Fu et al., 2008).

\section{Fourier Transform Infrared Spectroscopy Analysis}

The FTIR of Yellow oleander seed oil was analysed for its functional groups that qualifies it as triglycerides. The IR spectroscopy machined was warmed for 1 hour. The sampled oil to be analyzed was dried of water so that it does not affect the potassium chloride $(\mathrm{KCl})$ plates. The plates were thoroughly cleaned using acetone. Using a syringe pipette a drop of the sample oil was placed between the two $\mathrm{KCl}$ plates. The chloride plate was then attached to a Fourier Transform Infrared Spectrometer coupled to a computer with print out system. The sample in the plate was irradiated by infrared lamp source at one end of the spectrometer and each sample was analyzed between a range of $600 \mathrm{~cm}-1$ to $4000 \mathrm{~cm}-1$.

\section{Determination of Physico-Chemical Properties} of Yo

In this research, the following physico-chemical characteristics of Yellow oleander seed oil were determined using standard AOAC procedures; acid value, iodine value, saponification value, free fatty acid, peroxide value, viscosity, density, specific gravity and refractive index The refractive index, densities and calorific value was determined using ASTM D 2015 method ,1989.

\section{Determination of Saponification Value:}

The saponification value of the oil was determined using a reflux condenser fitted to a $250 \mathrm{~cm}^{3}$ conical flask containing an ionic solution of $2.0 \mathrm{~g}$ oil in $25 \mathrm{~cm}^{3}$ of $0.5 \mathrm{M}$ alcoholic $\mathrm{KOH}$ according to AOAC, (1980). The flask was heated in a water bath for an hour with frequent swirling to ensure that the sample was fully dissolved. The excess $\mathrm{KOH}$ was titrated hot with 0.5 $\mathrm{M} \mathrm{HCl}$ using $1 \mathrm{~cm}^{3}$ of phenolphthalein (1\%) solution until a pink endpoint was reached. A blank determination was also carried out. The saponification value was calculated using equation (ii). 
Bajopas Volume 10 Number 2 December, 2017

$$
\begin{aligned}
& \text { Saponification value (mg KOH/g oil) }=\frac{56.1 \times \mathrm{C} \times\left(\mathrm{V}_{\mathrm{O}}-\mathrm{V}\right)}{\mathrm{M}} \\
& \qquad \begin{aligned}
\text { Where: } \quad \mathrm{V}= & \text { Volume }\left(\mathrm{cm}^{3}\right) \text { of the } 0.5 \mathrm{M} \mathrm{HCl} \text { used in blank. } \\
\mathrm{V}_{\mathrm{O}} & =\text { Volume }\left(\mathrm{cm}^{3}\right) \text { of the } 0.5 \mathrm{M} \mathrm{HCl} \text { used in assay with oil). } \\
56.1 & =\text { mg of } \mathrm{KOH} \text { equivalent to } 1 \mathrm{~cm}^{3} \text { of } 0.5 \mathrm{M} \mathrm{HCl} \\
\mathrm{M} & =\text { mass in } \mathrm{g} \text { of oil used and } \\
\mathrm{C} & =\text { concentration of } \mathrm{HCl} \text { used. }
\end{aligned}
\end{aligned}
$$

Acid Value Determination :The acid number of the oil was determined by the ASTM-947(00) method with 0.5 $\mathrm{M}$ alcoholic sodium hydroxide, . The volume of $\mathrm{NaOH}$ used was recorded. The procedure was repeated for the blank and the acid value was computed according to equation (iii).

$$
\begin{gathered}
\text { Acid Value }(\mathrm{mg} \mathrm{KOH} / \mathrm{g} \text { oil })=\frac{56.1 \times \mathrm{C} \times \mathrm{V}}{\text { Weight of oil sample }(\mathrm{g})} \\
\text { Where, } \left.\mathrm{V}=\text { Volume of the sodium hydroxide used (in } \mathrm{cm}^{3}\right) \\
\mathrm{C}=\text { Molar concentration of sodium hydroxide }
\end{gathered}
$$

used

$$
56.1 \text { = Molar mass of } \mathrm{NaOH}
$$

Determination of the Percentage Free Fatty Acid (FFA) of the Oil: The FFA level of the oil was measured using the Pearson, 1991 method where the acid value determination was followed by the free fatty acid determination to ensure it is less than $1.0 \%$ from the relationship given by Norris (1965) in equation (iv)

Therefore: - \% Free Fatty Acid (FFA) = Acid Value $\times 0.503$

Where the FFA was found to be higher than $1.0 \%$, acid esterification was employed until the free fatty acid value was less than 1.0 .

Determination of Density:The densities of the oils were determined by ASTM method D - 1298 - (99).

The Iodine Value was determined using Wij"s reagent (AOCS, 1988) and calculated from the expression in equation (v)

$$
\text { Iodine value }=\frac{\left(V_{2}-V_{1}\right) \times C \times 12.69}{\text { Weight of sample }(g)}
$$

$$
\text { Where, } \begin{aligned}
\mathrm{C} & =\text { concentration of sodium thiosulphate used } \\
\mathrm{V}_{1} & =\text { volume of sodium thiosulphate used for sample } \\
\mathrm{V}_{2} & =\text { volume of sodium thiosulphate used for blank } \\
12.69 & =\text { Constant. }
\end{aligned}
$$

Determination of Refractive Index (ASTM D 2015 method., 1989). Refractive index of oil samples was determined at room temperature using Abbe refractometer.

Determination of Peroxide Value was determined according to AOAC, 2005 method. The titre value of

$$
\text { Peroxide value }(\mathrm{me} / \mathrm{kg} \text { oil })=\left(\mathrm{V}_{1}-\mathrm{V}_{0}\right) \times \frac{\mathrm{C} \times 1000}{\mathrm{M}}
$$

Where, $\quad M=\operatorname{mass}(\mathrm{g})$ of oil sample used.

thiosulphate solution.

$$
\mathrm{C}=\text { exact molarity }(0.1 \mathrm{M}) \text { of sodium }
$$

$0.1 \mathrm{M}$ sodium thiosulphate solution was recorded as $V_{1}$. Blank determination was also carried out and the volume recorded as $V_{0}$ and the peroxide value computed from the following relationship (vi)

$$
\mathrm{V}_{1}=\text { volume }\left(\mathrm{cm}^{3}\right) \text { of } 0.1 \mathrm{M} \mathrm{Na} \mathrm{S}_{2} \mathrm{O}_{3} \cdot 5 \mathrm{H}_{2} \mathrm{O} \text { used for sample }
$$
titration.

\section{Determination of Fuel Properties of the Oil}

The following fuel properties of the of the two oils were determined using ASTM standard methods: viscosity, density, pour point, cloud point, water content, acid value, cetane index, ash content and

$$
\begin{aligned}
& \mathrm{V}_{0}= \text { volume }\left(\mathrm{cm}^{3}\right) \text { of } 0.1 \mathrm{M} \mathrm{Na} \mathrm{S}_{2} \mathrm{O}_{3} \cdot 5 \mathrm{H}_{2} \mathrm{O} \text { used for blank } \\
& \text { titration. } \\
& \text { sulphur content. The fuel properties of the oils were } \\
& \text { compared with the latest American Standard for } \\
& \text { Testing Material (ASTM D 6751) and European } \\
& \text { standard for biodiesel. }
\end{aligned}
$$




\section{Colour of the oils}

The visual determination of the colour of the biodiesel was done using ASTM D - 1500 (98) approach. The containers were covered to exclude all exterior light. The light source was switched on and the colour of the sample compared with the standard glasses ranging from 0.5 to 4.5 .
A Redwood viscometer was used to measure the Kinematic Viscosity (ASTM D445) of the samples. The kinematics viscosity ( $v$ ) was calculated by means of the equation (3.9) adapted from Sandford et al., 2009:

$$
\begin{aligned}
& \text { Calculation: } \mathrm{V}=\mathrm{C} \times \mathrm{t} \\
& \qquad \begin{aligned}
\text { Where, } \mathrm{V} & =\text { Kinematic Viscosity in }\left(\mathrm{mm}^{2} / \mathrm{s} \text { or cSt }\right) \\
\mathrm{t} & =\text { mean flow time }(\mathrm{s}) \text { of } 50 \mathrm{ml} \text { sample } \\
\mathrm{C} & =\text { Viscosity tube constant }(0.09757 \text { or } 0.1029),\left(\mathrm{mm}^{2} / \mathrm{s}\right) / \mathrm{s}
\end{aligned}
\end{aligned}
$$

Flash Point Determination (ASTM D93, 2008). The flash point was measured with a Pensky-Martens closed cup tester (Koehler Instrument Company, Inc. K16200). A temperature reading taken immediately a flash appeared on the surface of the sample was referred to as the flash point of the oil.

Cloud Point Analysis (ASTM D2500, 2005). The temperature that corresponds to the first formation of a cloud in the fuel sample was recorded as the cloud point.

The ASTM D-97 standard method was adopted for the pour point test. The lowest temperature at which sample movement is observed was noted and recorded and $3{ }^{\circ} \mathrm{C}$ was added to the recorded temperature to give the pour point.
Sulphur Content Determination (ASTM D2622). Sulphur in the samples was determined by $X$ ray or spectroscopy following the ASTM D-2622 method.

Test for Cetane Number (ASTM D 613, 2010) . Engine used for rating gasolines was used to determine the cetane number of the oils. The primary reference fuel used was n-cetane (n-hexadecane), which has a cetane number of 100 and heptamethylnonane (HMN), which has a cetane number of 15 . When the ignition delay was restored to 13 degrees, the cetane number was then computed from the following relationship:

$$
\text { Cetane Number }=\% \text { n-cetane }+0.15(\% \mathrm{HMN})
$$

The Calorific Value of the oil was determined (ASTM D2015, 1989) using the bomb calorimeter.

\section{RESULTS}

Oil Yield and Physicochemical Properties of YO: The yellow oleander seeds oil (YO) was found to contained $64.7 \%$ oil and can be classified as high yielding oil. A summary of the values the physicochemical properties of the oil are presented in Table I, with acid value $(1.26 \mathrm{mg} / \mathrm{g})$, peroxide value (3.0 $\left.\mathrm{meqO}_{2} / \mathrm{kg}\right)$, iodine value $(75.82 \mathrm{~g} / \mathrm{g})$, saponification value (197.75 $\mathrm{mg} \mathrm{KOH} / \mathrm{g})$, specific gravity $\left(0.88406 \mathrm{~g} / \mathrm{cm}^{3}\right)$ and refractive index 1.4791$)$. The Fuel Properties of YO: The fuel properties of the $\mathrm{YO}$ are shown in Table I. The flash point $\left(192^{\circ} \mathrm{C}\right)$, cloud point $\left(10^{\circ} \mathrm{C}\right)$, cetane number $\left(48^{\circ} \mathrm{C}\right)$, Calorific value $(13.7858 \mathrm{MJ} / \mathrm{kg})$ and kinematic viscosity $(23.23$ $\mathrm{mm}^{2} / \mathrm{s}$ ) are values for oleander oil.

TABLE 1: Physicochemical Properties of YO.

\begin{tabular}{ll}
\hline Property & YO \\
\hline Oil Yield $(\%)$ & $64.70 \pm 0.53$ \\
Acid value $(\mathrm{mg} / \mathrm{g})$ & $1.26 \pm 0.02$ \\
Free fatty acid \% & $0.63 \pm 0.02$ \\
Iodine value $(\mathrm{g} / \mathrm{g})$ & $75.82 \pm 1.44$ \\
Refractive index value & $1.48 \pm 0.02$ \\
Specific gravity $\left(\mathrm{g} / \mathrm{cm}^{3}\right)$ & $0.88 \pm 0.02$ \\
Peroxide value $\left(\mathrm{meq} \mathrm{O}_{2} / \mathrm{kg}\right)$ & $3.00 \pm 0.36$ \\
\hline
\end{tabular}

Values are presented as mean \pm SD and are for duplicate analysis of each sample.

TABLE 2: Fuel Properties of YO as Compared to SBD and FD.

\begin{tabular}{lllc}
\hline Property & YO & SBD & FD \\
\hline Flash point $\left({ }^{\circ} \mathrm{C}\right)$ & 192 & $100-170$ & $60-80$ \\
K.Viscosity $\mathrm{mm}^{2} / \mathrm{s}$ & 23.23 & $1.9-6.0$ & $1.3-4.1$ \\
Cetane Number & 48 & - & - \\
Diesel index & 25 & - & - \\
ASTM colour & 0.5 & - & - \\
Cloud point ${ }^{\circ} \mathrm{C}$ & 14 & $-3-12$ & $-15-5$ \\
Calorific value $(\mathrm{MJ} / \mathrm{kg})$ & $1378 \pm 0.58$ & - & - \\
Sulphur $(\%)$ & 0.003 & - & - \\
\hline
\end{tabular}

$\mathrm{FD}=$ FOSSIL DIESEL ; SBD = SOYBEAN DIESEL 
Fatty Acid Profile of YO.

Figure. 1 shows the GC-MS spectra of YO. The percentage composition of the fatty acids consists of the following categories of fatty acids; saturated (myristic (14:0), palmitic (16:0), marganic (17:0), stearic (18:0), arachidic (20.0), behenic (22:0)), monounsaturated (palmitoleic (16:1), oleic (18:1), erucic (22:1), elaidic (18:1) and polyunsaturated (linoleic (18:2), linolenic (18:3) is shown in Table 3. Palmitic acids (23.89\%), stearic acids $(10.92 \%)$, oleic acid(16.11\%) and elaidic acid (24.83) and lenoleic (19.79) were recorded as high in yellow oleander oil.

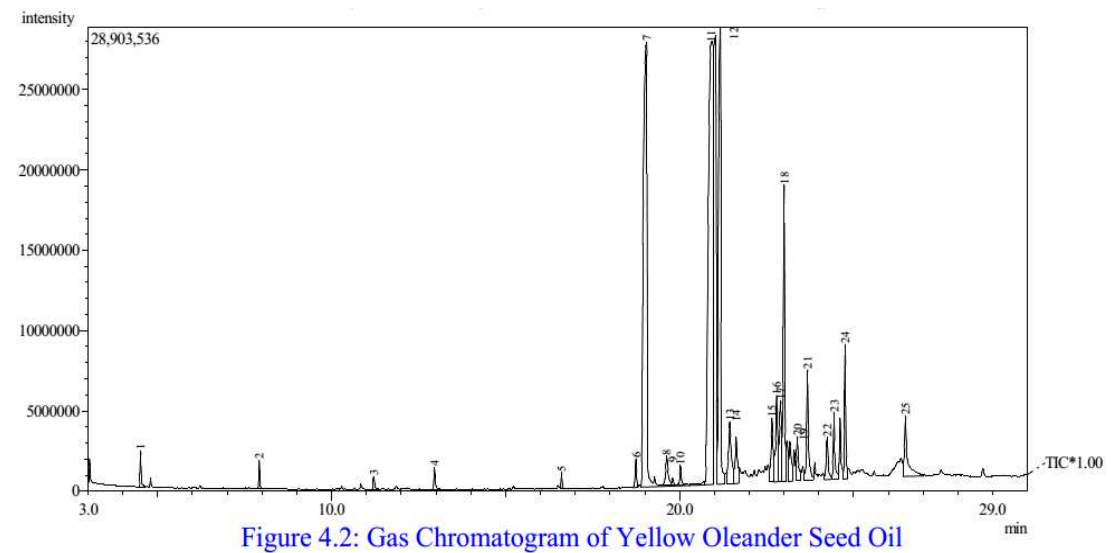

FIGURE 1: Gas Chromatogram of YO

TABLE 3: Fatty Acid Profile of YO

\begin{tabular}{lcl}
\hline Properties & YO & *Heat of combustion (J/kg) \\
\hline Saturated acids & $\mathbf{3 8 . 5 3 \%}$ & $\mathbf{2 0 7 3 . 9 1}$ \\
Myristic (14:0) & 0.14 & $\mathbf{2 3 8 4 . 7 6}$ \\
Palmitic (16:0) & 23.89 & - \\
Marganic (17:0) & $\overline{\mathbf{2 6 9 6 . 1 2}}$ \\
Stearic (18:0) & 10.92 & - \\
Arachidic (20.0) & 2.54 & - \\
Behenic (22:0) & 1.04 & - \\
Mono-unsaturated acids & $\mathbf{4 1 . 2 1 \%}$ & $\mathbf{2 6 5 7 . 4 0}$ \\
Palmitoleic(16:1) & 0.27 & - \\
Oleic (18:1) & 16.11 & - \\
Erucic (22:1) & $\overline{1}$ & - \\
Elaidic (18:1) & 24.83 & - \\
Polyunsaturated & $\mathbf{2 0 . 2 6 \%}$ & \\
Linoleic (18:2) & 19.79 & \\
Linolenic (18:3) & 0.47 & \\
Total & & \\
Monounsaturated & & \\
Total polyunsaturated & $\mathbf{7 9 . 6 4 \%}$ & \\
& $\mathbf{2 0 . 2 6 \%}$ & \\
\hline
\end{tabular}

*Oseni et al., 2012

TABLE 4: Positions of FTIR Peaks in Wavenumbers $\left(\mathrm{cm}^{-1}\right)$ of Untreated YO (at $28^{\circ} \mathrm{C}$ ).

YO (Untreated) Assignment

Region of hydrogen's stretching.

3471.98

$-\mathrm{OH}$ stretching vibration of the triglycerides

2924.18

-Symmetric and asymmetric stretching vibration of the aliphatic $-\mathrm{CH}_{2}$ and $-\mathrm{CH}_{3}$ group.

1744.67

1455.34
Region of double bond's stretching

-ester carbonyl functional group of the triglycerides

$-\mathrm{C}=\mathrm{C}$ stretching vibration of olefins

Region of other bonds deformations and bendings

- Bending vibrations of $\mathrm{CH}_{2}$ groups

Fingerprint region

-C- O stretching vibration of ester group

- $\mathrm{CH}_{2}$ rocking vibration and the out of plane vibration of disubstituted olefins 


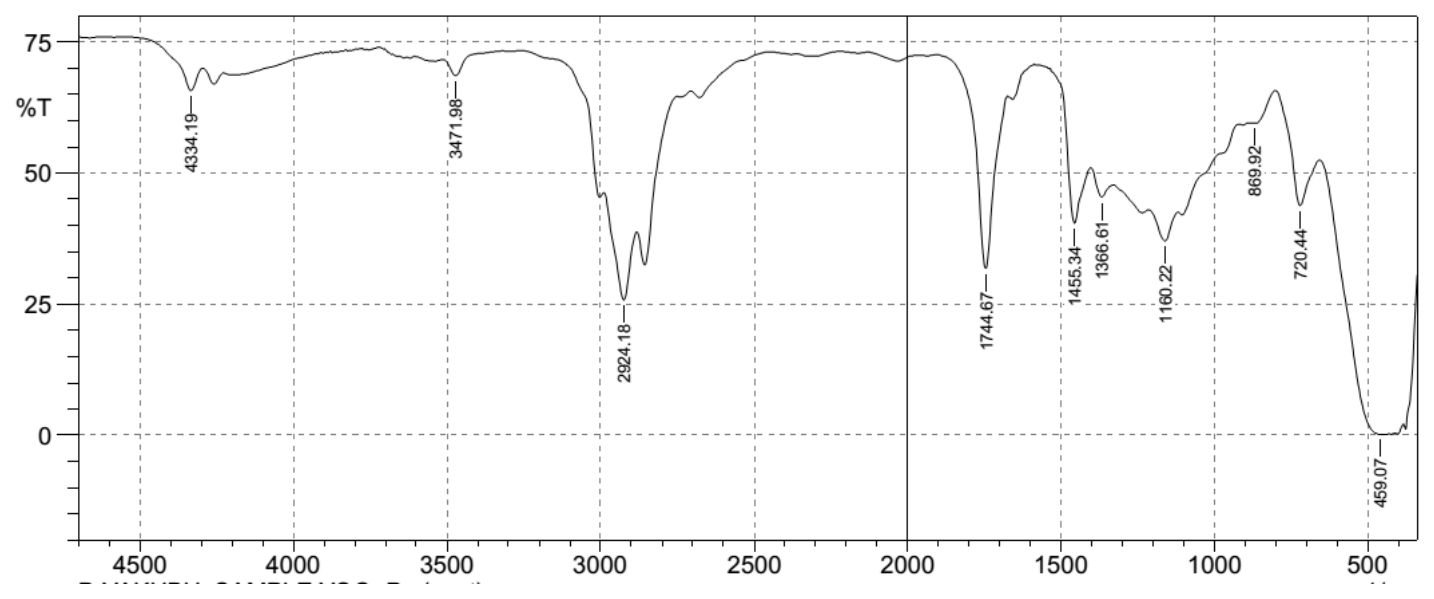

DISCUSSION

\section{Oil Yield of Yellow Oleander Seed}

The $64.7 \%$ oil content of the Yellow Oleander (YO) plant seeds obtained in this work compares favourably with the oil yields of Yellow Oleander seeds $(61.8 \%$ $64.7 \%$ ) reported by Ibiyemi et al. (2002). This value also compares with other oil bearing plants such as jatropha kernel (63.16 \%) as reported by Emil et al., (2009). The result is within the range of oil content of $30-65 \%$ from Calophyllum inophyllum reported by Azam et al., (2005). However, the oil yields are higher than those of Azadirachta indica (44.5\%), Pangamia pinnata (33\%) and Ziziphus mauritiana (33\%) Azam et al., (2005). The pig lard (PL) yield of $70 \%$ to $93 \%$ reported by Clemen (1927) agrees with the yield 85.4 $\%$ obtained in this work. These oils can be classified as commercially viable for production of biodiesel. (Ikhuoria et al., 2008; Emil et al., 2009).

\section{Physicochemical Properties of YO}

\section{i Specific Gravity}

The specific gravity values of $\mathrm{YO}$ are in agreement with other results found for $T$. africana samples by Dawodu,( 2009). However, lower values of 0.426 have been reported for soybean oil by Oladiji et al., (2010). Generally, plant oils with specific gravity of 0.8200 to 1.0714 at $30^{\circ} \mathrm{C}$ are considered good for use as biofuels (Bhattacharya, et al., 2013 and Minzagi et al., 2011).

\section{ii. Acid Value}

The acid value which is an important property used to indicate the quality, age and suitability of oils for use in the biodiesel industry was found to be $1.26 \mathrm{mg} / \mathrm{g}$ in YO (Table 1). This value was observed to be lower than that reported by Minzangi et al (2011) and Zaku et al, (2012) in some non-edible oils of Azadirachta indica (17.40 mg KOH/g), Ricinus communis (12.48 $\mathrm{mg} \mathrm{KOH} / \mathrm{g})$, Moringa oleifera $(4.96 \mathrm{mg} \mathrm{KOH} / \mathrm{g})$ and Jatropha curcas (8.43 mg KOH/g) seeds. The low acid value for YO implies low constituent of glyceride (Demian, 1990) and also suggests that it will be more susceptible to lipase action and will decomposed fast. Based on the acid value obtained, the free fatty acid content of YO was calculated as $0.63 \%$. The value of $\mathrm{YO}$ is close to the critical value $(0.5 \%)$ required for acid pretreatment for transesterification. The maximum acid value recommended by Canakci and Van Gerpen, (2001) for alkaline transesterification is $2 \mathrm{mg} \mathrm{KOH} / \mathrm{g}$ oil. Low oil acidity in $\mathrm{YO}$ indicates its suitability for use in the biodiesel industry (Akubugwo et al, 2008). There will be high biodiesel yield, since the low acid value will not inhibit the formation of methoxides nor neutralize the base - catalyst to produce soaps within the reaction medium, which would exacerbate the problem of phase separation at the stage of product recovery (Meneghetti et al., 2006).

\section{iii. Peroxide Value}

The peroxide value is an indication of the amount of hydroperoxides present in oil. These compounds arise from lipid oxidation; therefore, the peroxide value, expressed as milliequivalent oxygen per kilogram oil $(\mathrm{meq} / \mathrm{kg})$, is a measure of oil quality. The results show peroxide value of $3.20 \mathrm{mEq} / \mathrm{kg}$ in YO (Table $1)$. This value is within the range of $0-10 \mathrm{meq} / \mathrm{kg}$ which is stipulated for freshly prepared oil (Cooks and Reds, 1996). The low peroxide value implies good oxidative stability and high resistance to hydrolysis. This corroborates the fact that YO has high resistant to hydrolysis and oxidative deterioration, hence it is of good quality, with lower tendency to go rancid on storage. Therefore, storage for a long time may not likely affect the quality of the oil (Anyasor et al, 2009; Atasie et al, 2009).

\section{iv. Saponification Value}

The saponification values is $197.75 \pm 0.72$ in YO (Table 4.1). These values fall within the range of $182.5-$ $260 \mathrm{mg} \mathrm{KOH} / \mathrm{g}$ reported by Minzangil et al, (2011) for oils obtained from plant species. They also indicate that the oils are normal triglycerides and have the potential to be developed into biodiesel fuel (Akbar et $a l$, 2009). The low saponification value might imply the presence of long chain fatty acids of high molecular mass with a relatively fewer number of carboxylic functional groups per unit mass of $\mathrm{YO}$ (Denniston et al, 2004). As a result of the high mass, the saponification value and acid value were low. 


\section{v. Iodine Value}

Table I shows iodine value to be $75.82 \mathrm{~g} / \mathrm{g}$ for YO. The moderately high percentage of unsaturated fatty acids recorded in $\mathrm{YO}$ is supported by the iodine value in this study. YO consists of $41.21 \%$ unsaturated fatty acid of oleic, elaidic, and linoleic acid while, Sus domesticus has $35.9 \%$ unsaturated fatty acids (Table 3 ). The iodine value corroborated with the higher precent of unsaturated fatty acids in YO. The Iodine value of oils directly affects stability with regards to oxidation. Small amounts of more highly unsaturated fatty compounds have a disproportionately strong effect (Knothe and Dunn, 2003). The moderate iodine values recorded in $\mathrm{YO}$ and $\mathrm{PL}$ make them relatively stable to oxidation and are likely to be stored for a reasonably long period of time without becoming rancid (Firestone, 1994). They are therefore likely to be good feedstock in biodiesel industry.

\section{vi. Refractive Index}

The refractive index for YO was found to be 1.4791, close to the value of 1.461 reported by Eshun et al. (2013) for peanut oil. These refractive indices tend to correlate with the degree of unsaturation or iodine value, and showed that both oils are clear and bright (less1.47) with no contamination or rancidity (Karabulut, et al,; 2003).

\section{vii Kinematic Viscosity}

The kinematic viscosity $23.23 \mathrm{~mm}^{2} / \mathrm{s}$ of YO imply low volatility which will reduce fuel atomization and cause the oil not to burn completely. This problem of high viscosity can be reduced by transesterification reaction (Atadashi et al., 2011) and enhances other physicochemical properties of the oil (Ferella et al., 2010).

viii. Free Fatty Acid (FFA)

The percentage free fatty acid of YO was calculated as $0.63 \%$ (Table I). This suggests that the transesterification of $\mathrm{YO}$ into biodiesel would be economical as pretreatment may not be necessary(Dorado et al., 2002).

ix. The calorific value

The calorific value of $\mathrm{YO}$ was found to be $13.7858 \mathrm{MJ} / \mathrm{kg}$. This will allow for efficient combustion when used as fuel (Table I). The predominant fatty acids in YO were found to be palmitic acid $(23.61 \%)$, stearic acid (10.78\%) and oleic acid (16.58\%) which might have contributed significantly to the heat of combustion of the oil (Table III). Stearic acid, a saturated fatty acid whose heat of combustion has

\section{REFERENCES}

Akbar E., Yakoob Z., Kamarudin, S.K.., Ismail, M., Salimon, J. (2009). Characteristics and Composition of Jatropha Curcas oil seed from Malaysia and its potential as biodiesel feedstock. European Journal of Scientific Research, 29, 396-403.

Abdulkadir B. A., Danbature W., Yirankinyuki F. Y., Magaji B. and Muzakkir M. M. (2014). In Sit Transesterification of Rubber Seeds (Hevea brasiliensis). Greener Journal of Physical Sciences, Vol. 4 (3), pp. 038-044. been determined as 2,696.12 J/kg was a major contributor to this calorific value. Another significant contributor to this calorific value could be palmitic acid, also a saturated acid, with heat of combustion of $2,384.76 \mathrm{~J} / \mathrm{kg}$. The contribution of oleic acid with heat of combustion of $2,657.4 \mathrm{~J} / \mathrm{kg}$ could be significant (Table III). YO showed good calorific values and can therefore be considered good feedstocks for biodiesel production (Vairavan et al., 2010).

$x$. The FTIR Spectra Peaks of YO The exact position of the band of each functional group is determined by the composition of the oil. Hence, the IR spectra of YO shows two strong, sharp and notable bands at $2924.18 \mathrm{~cm}^{-1}$ which are attributed to the symmetric stretching vibration of the aliphatic $\mathrm{CH}_{2}$ group (Figures 4.3). This may be due to the presence of $20.26 \%$ of linolenic acid and 16.11 $\%$ oleic acid groups in YO. This is in accordance with similar observations made by Guillen and Cabo (1999). Additional Signals were observed at $716-720$ $\mathrm{cm}^{-1}$ which were assigned to $-\mathrm{CH}_{2}$ rocking vibration of the oil. The strong absorption bands in the IR spectrum (Table 4.4) at 1739 to $1745 \mathrm{~cm}^{-1}$, are characteristic of carbonyl ( $-\mathrm{C}=\mathrm{O}$ vibration) group of esters in YO. All aspects regarding the carbonyl group signals were visible in the spectrum.

\section{CONCLUSION}

The non-edible YO which gave high oil yield, can serve as available raw materials for the production of biodiesel. The physicochemical properties of YO such as specific gravity, acid value, iodine value, kinematic viscosity, flash point, iodine value, peroxide value, cloud point and refractive index are similar to biodiesel properties. Their high specific gravities and low acid values are in the range of oils considered good raw materials for biodiesel production. The high kinematic viscosities of the oils will lead to poor fuel performance in diesel engine.

The presence of carbonyl functional group of the triglycerides was observed at $1739 \mathrm{~cm}^{-1}-1745 \mathrm{~cm}^{-1}$ in the IR spectrum. The ester group $\mathrm{R}-\mathrm{C}(\mathrm{OR})=\mathrm{O}$ showed triglyceride peaks at $1160 \mathrm{~cm}^{-1}$.

The GC-MS analysis of the yellow oleander revealed the major fatty acid component as oleic acid, palmitic acid and stearic acid. The fuel parameters of YO such as flash point, cetane number, specific gravity, were found to be in agreement with the American ASTM D6751. Hence YO may be considered a good source of raw material for biodiesel production.

Ahmad A.L., YasinN.H.M., DerekC.J.C., LimJ.K. (2011) . Microalgae as a sustainable energy source for biodiesel production: a review. $R e$ newable \& Sustainable Energy Reviews,15: 584-93.

Akubugwo, I. E., Obasi, N. A.,Chinyere, G. C. and Ugbogu, A. E.(2008). Mineral and phytochemical contents in leaves of Amaranthus hybridus . and Solanum nigrum L. subjected to different processing methods. African journals of biochemistry research. Vol. 2(2),pp. 040-044 
Anyasor, G.N., Ogunwenmo, K.O., Oyelana, O.A., Ajayi, D. and Dangana, J. (2009). Chemical Analyses of Groundnut (Arachis hypogaea) Oil. Pakistanian Journal of Nutrition, 8(3): 269-272.

AOAC (1980). Official Method of Analysis. 14th Edition. Association of Official Analytical Chemists, 7: 56-

132. William Horwitz. Ed.Washington, DC. AOAC (1984).Official Method of Analysis. Fifteenth Edition. Association of Official Analytical Chemists, 7: 56-132.

William Horwitz. Ed.Washington, DC. AOAC (2005). Official Methods of Analysis. 19th Edn. Association of Official Analytical Chemists, Washington, DC. USA. 14.

AOCS (2003). Official Method Cd 8-53. American Oil Chemists Society, Champaign, IL.

Aransiola, E.F., Betiku, E., Ikhuomoregbe, D.I.O. and Ojumu, T.V., (2012). Production of biodiesel from crude neem oil feedstock and its emissions from internal combustion engines. African Journal of Biotechnology, 11(22): 6178-6186.

ASTM Standard D2015-85 (1989). Standard test method for gross calorific value of coal and coke by the adiabatic bomb calorimeter, in gaseous fuel; coal and coke, section 5, vol.0.5-05, ASTM International, West Conshohocken, PA, 1989: 251.

ASTM D2500 - 17a (2005). Standard Test Method for Cloud Point of Petroleum Products and Liquid Fuels : Book of Standards Volume: 05.01

ASTM D93 (2008). Test Methods for Flash Point by Pen\&y-Martens Closed Cup Tester: Annual Book of ASTM Standards, Vol 05.01.

ASTM D613 - 17ce1 (2010). Standard Test Method for Cetane Number of Diesel Fuel Oil: Book of Standards Volume: 05.05

Atadashi, I.M., Aroua, M.K. and Aziz, A.A. (2011). Biodiesel separation and purification: A review. Renewable Energy, 36: 437 - 443.

Atasie, V.N., Akinhanmi , T.F., Ojiodu, C.C. (2009). Proximate Analysis and Physico-Chemical Properties of Groundnut (Arachis hypogaea L.). Pakistanian Journal of Nutrition, 8(2):194-197.

Azam, M. M., Waris, A. and Nahar, N.M. (2005).Prospects and potential of fatty acid methyl esters of some non-traditional seed oils for use as biodiesel in India. Biomass and Bioenergy, 29:293-302.

Bhattacharya, C. Pandey, B. Paroha, S. (2013). Effect of physico-chemical changesin Sesame Sesamum indicum L.) Seeds due to Storage. Asian Journal of Biological and Life Sciences, 2(3): 254-257.

Canakci, M. and Van Gerpen, J.H. (2001). "Biodiesel production from oils and fats with high free fatty acids". Transactions of the American Society of Agricultural Engineers, 44(6):1429-36.
Clemen R. A., (1927). By-products in the packing industry. University of Chicago Press. Pp. 89.

Cooks, L.V. and Reds, B.C.(1996). Laboratory Handout for Oils and Fats Analyst. (U.S Edition). Academy Press Inc. London. pp.419-421.

Dawodu, F.A. (2009). Physico-chemical studies on oil extraction processes from some Nigerian grown plant seeds. Electronic Journal of Environment and Agricultural Food Chemistry, 8(2): 102-110.

Demian M.J. (1990). Principles of Food Chemistry. $2^{\text {nd }}$ Ed. Van Nostrond Reinhold International Company Limited, London England pp. 3738.

Denniston, K.J., Topping, J.J. and Caret, R.L. (2004.): General, Organic and Biochemistry, 4thEd. McGraw Hill Companies, New York, pp: 432433.

Dorado, M.P., Ballesteros, E., Almeida, J.A., Schellet, C., Lohrlein, H.P., Krause, R. (2002)."An alkali-catalyzed transesterification process for high free fatty acid oils". Transactions of the American Society of Agricultural Engineers-ASAE, 45(3):525-925.

Emil, A., Yaakob, Z., Kumar, M.N.S., Jahim, J.M. and Salimon, J. (2009). Characteristic and Composition of jatropha seed oil from Malaysia and its potential as biodiesel feedstock. European Journal of science, 29: 396-403.

Ferella, F., Mazziotti, G., De Michelis, I., Stanisci ,V. and Veglio, F. (2010). Optimization of the tranesterification reaction in biodiesel production. Fuels, 89: $36-42$.

Firestone, D. (1994). "Determination of the iodine value of oils and fats: summary of collaborative study". Journal of the Association of Official Analytical Chemists AOAC, 77(3): 674-676.

Fu, Y.J., Zu ,Y.G., Wang, L.L., Zhang, N.J., Liu, W., Li, S.M. and Zhang, S., (2008). Determination of Fatty Acid Methyl Esters in Biodiesel Produced from yellow horn oil by RP-LCRID. Chromatographia, 67: 9-14.

Guillen S. and Cabo N. (1999). Infrared Spectroscopy in the study of eEdible Oils and Fats. Journal of Science Food and Agriculture. 75 : 1-11.

Hassan S.N.A.M., Ishak M.A.M., Ismail K., Ali S.N., Yusop M.F. (2014). Comparison Study of Rubber Seed Shell and Kernel (Hevea Brasiliensis) as Raw Material for Bio-oil Production. Energy Procedia Vol.52, pp.610617. 2013 International Conference on Alternative Energy in Developing Countries and Emerging Economies (2013 AEDCEE).

Ibiyemi, S. A., Fadipe, V. O., Akinremi, O. O. and Bako, S.S. (2002). Variation in oil composition of Thevetia peruviana Juss (Yellow Oleander) fruits seeds. Journal of Applied Science and Environmental Management. (JASEM), 6 (2): $61-65$. 
Ikhuoria, E.U., Aiwonegbe, A.E., Okoli, P., Idu, M. (2008). Characteristics and composition of African oil bean seed (Pentaclethra macrophylla Benth). Journal of Applied Science, 8(7): 1337-1339.

Izah S. C.; Ohimain E. I. (2013). The challenge of biodiesel production from oil palm feedstock in Nigeria Greener Journal of Biological Sciences, Vol. 3 (1), pp. 001-012.

Jahirul M. I., Brown R. J., Senadeera W., O'Hara I. M. and Ristovski Z. D. (2013). The Use of Artificial Neural Networks for Identifying Sustainable Biodiesel Feedstocks. Energies 6, 3764-3806; doi:10.3390/en6083764

Khandelwal S. and Chauhan. Y. R.(2012).Biodiesel production from non edible-oils : A Review: Journal of Chemical and Pharmaceutical Research, 4(9):4219-4230. .

Karabulut, I., Kayahan, M., Yaprak, S. (2003). Determination of changes in some physical and chemical properties of soybean oil during hydrogenation. Food Chemistry, 81: 453- $\quad 456$

Knothe, G. and Dunn R.O. (2003). Dependence of Oil Stability Index of Fatty Compounds on their Structure and Concentration and Presence of Metals. Journal of the American Oil Chemists Society, JAOCS, 80(10):1021-1026

Meneghetti, S.M.P. Meneghetti M.R., Wolf C.R., Silva E.C., Lima G.E.S., Silv L.L.S., Serra T.M., Cauduro F. , Oliveira L.G. (2006). Biodiesel from castor oil: a comparison ethanolysis versus methanolysis. Energy Fuel, 20 (2006), pp. 2262-2265

Minzangi, K., Kaaya, A. N., Kansiime, F., Tabuti, J. R.S. and Samvura, B. (2011). Oil content and physicochemical characteristics of some wild oilseed plants from Kivu region Eastern Democratic Republic of Congo. African Journal of Biotechnology, 10 (2): 189- 195.

Mohammed N. I., Kabbashi N.A., Alam M. Z. and Mirghani M. E. (2014). Jatropha Curcas Oil Characterization and Its Significance for Feedstock Selection in Biodiesel Production. $20145^{\text {th }}$ International Conference on Food Engineering and Biotechnology IPCBEE vol.65. 12.

Moser, B.R. Knothe, G. Vaughn, S.F. Isbell, T.A. (2009). Production and evaluation of biodiesel from Field Pennycress (Thlaspi arvense L.) oil. Energy Fuels, 23: 4149-4155

Norris, F.A. (1965). Fats and Fatty Acids, In: KirkOthmer Encyclopedia of Chemical Technology, Vol. 8; John Wiley, New York, pp: 170-886.

Oladiji A. T., Yakubu M. T., Idoko A. S., Adeyemi O. and Salawu M. O.(2010). Studies on the physicochemical properties and fatty acid composition of the oil from ripe plantain peel (Musa paradisiaca). African Scientist; Vol.11. No. 1,pp.73- 78.
Oluwaniyi, O.O. and Ibiyemi, S.A. (2007). Extractability of thevetia peruviana glucosides with alcohol mixture. African Journal of Biotechnology, 6:.2166-70.

Oseni, M. I, Obetta, S. E. and Orukotan, F. V.(2012).Evaluation of fatty acids profile of ethyl esters of yellow oleander and groundnut oils as biodiesel feedstock. American Journal of Scientific and Industrial Research, 3(2): 62-68.

Padhi, S.K., Singh, R.K.(2010). Optimization of esterification and transesterification of Mahua (Madhuca Indica) oil for production of biodiesel. Journal of Chemical and Pharmaceutical Research, 2(5):599-608.

Patel N. K., Nagar P. S., Shah S.N. (2013). Identification of Non-edible Seeds as Potential Feedstock for the Production and Application of Bio-diesel. Energy and Power, 3(4): 67- 78.

Raheman, H. and Ghadge, S.V. (2007). Performance of compression ignition engine with mahua (Madhuca indica) biodiesel. Fuel, 86: 25682573.

Raufu M.O., Olawuyi S.O., Fayemo K.A., Akintola R.O. (2014). Economics of biodiesel production from Jatropha curcas L.in Nigeria. International Journal of Development and Sustainability Volume 3 Number 4: Pp. 908916.

Sanford, S.D., White, J. M., Shah, P. S., Wee, C., Valverde, M. A. and Meier, G. R. (2009).Feedstock and biodiesel characteristics report, Renewable Energy Group, Inc.

Shay, E.G. (1993). Diesel fuel from vegetable oils: status and opportunities. Biomass Bioenergy, 4(4): pp.227-242.

Tunaru S., Althoff T.L., Nüsing R.M., Diener M. and Offermanns S. (2012).Castor oil induces laxation and uterus contraction via ricinoleic acid activating prostaglandin $\mathrm{EP}_{3}$ receptors. Proceedings of the National Academy of Sciences of the United States of America .Vol. 109(23) : 9179-9184.

Vairavan, K., Thukkaiyannau, P., Paramathma, M., Venkatachalam, P. and Sampathrajan, A. (2010). Biofuels Crops: Cultivation and Management, Jatropha, Sweet sorghum and Sugarbeet. Agrobios (India), Jodhpur, India, pp 3-9, 68-92.

Yarkasuwa C. I., Wilson D., and Michael E. (2013). Production of Biodiesel from Yellow Oleander (Thevetia peruvian) Oil and its Biodegradability. Journal of the Korean Chemical Society, Vol. 57, No. 3

Zaku S.G., Emmanual S. A., Isa A.H. and Kabir A. (2012). Comparative Studies on the Functional Properties of Neem, Jatropha, Castor, and Moringa Seeds Oil as Potential Feed Stocks for Biodiesel Production in Nigeria . Global Journal of Science Frontier Research Chemistry Volume 12 Issue 7 Version 1.0. 